\title{
Study on Sustaining Sugarcane Productivity through Mobilization of Nutrients using Bio-Inoculants
}

\author{
E. Jamuna* and M. Pandiyan \\ Department of Agricultural Microbiology, Agricultural College and Research Institute, Tamil \\ Nadu Agricultural University, Vazhavachanur - 606 753, Tamil Nadu, India \\ *Corresponding author
}

\section{A B S T R A C T}

\section{Keywords}

Sugarcane, Nitrogen fixing bacteria, $G$. diazotrophicus, Azospirillum

Article Info

Accepted:

04 September 2019

Available Online:

10 October 2019
Field experiment was undertaken to evaluate the response of sugarcane variety $\mathrm{CoC} 24$ to application of bioinoculants, viz., Gluconoacetobacter diazotrophicus, AM fungi and Azophos (Azospirillum and phosphobacteria), under different levels of $\mathrm{N}, \mathrm{P}_{2} \mathrm{O}_{5}$ and $\mathrm{K}_{2} \mathrm{O}$ inorganic fertilizer. The results revealed that the application of mycorrhizae, $G$. diazotrophicus, Azospirillum and phosphobacteria significantly produced higher cane yield in plant crop. The application of Gluconoacetobacter diazotrophicus @10 kg + AM fungi @ 50 kg/ ha + Azophos @ $10 \mathrm{~kg}+75 \%$ NPK recorded higher germination $(87.36 \%)$ and maximum tiller population $(1,94,185 / \mathrm{ha})$. The soil samples were collected before planting and after application of inorganic fertilizers and bioinoculants and were analyzed for the microbial population count and also for the dynamics in the soil nutritional status. The bacterial, fungal and diazotrophs population was also maximum with the application of $G$. diazotrophicus + AM fungi + Azophos $+75 \%$ NPK. It also significantly enhanced the total nitrogen content, available phosphorous, potassium and organic carbon content in the soil. We have also recorded the maximum mean millable cane population of 1.32 lakhs /ha, cane yield (137.45 t/ha) and sugar yield (16.96 t/ha). Applied bacterial sources helped in nitrogen fixation. Continuous mobilization and solubilisation of nutrients and their persistence and colonization in soil was an added advantage which also enhanced the soil fertility.

\section{Introduction}

Sugarcane is an important industrial crop of the Indo Gangetic plain region of South Asia with an approx. 4.2 million hectare area in India where rice - wheat sugarcane crop rotation is the major production system. The extensive cereal based cropping and lack of legumes led the soil poor in organic carbon content. Sugarcane is a very demanding crop, as for a cane yield of $100 \mathrm{t} / \mathrm{ha}$, it needs about $205 \mathrm{~kg} \mathrm{~N}, 55 \mathrm{~kg} \mathrm{P}_{2} \mathrm{O}_{5}, 275 \mathrm{~kg} \mathrm{~K}_{2} \mathrm{O}$ and a large amount of micronutrients from soil (Yaduvanshi and Yadav, 1990).

Since its fertilizer consumption is higher than that of other crops it has negative effect on soil health in the long term. 
In order to sustain productivity, major nutrients are provided each year at the recommended application rates of $150 \mathrm{~kg} / \mathrm{ha}$ of $\mathrm{N}$ and $60 \mathrm{~kg}$ each of $\mathrm{P}_{2} \mathrm{O}_{5}$ and $\mathrm{K}_{2} \mathrm{O}$ for sugarcane. The efficiency of sugarcane to utilize $\mathrm{N}$ range between 16 and $45 \%$ as large quantities of applied $\mathrm{N}$ leach down through soil layer due to irrigation (Yadav and Prasad 1992). Deterioration in the physico-chemical and biological properties of soil is considered to be the prime reason for declining sugarcane yield and productivity. The bio-fertilizer application increases crop growth through combination of BNF, growth promoting / hormonal substances, increased availability of soil nutrients and disease resistance. The importance of bio-fertilizer lies in the ability to supplement/ mobilize soil nutrients with minimal use of non renewable resources.

Endophytes play major role in sugarcane cultivation and in broader term endophytes includes fungal, actinomycetes and bacterial forms. They reside with in the interior of plants without causing disease or forming symbiotic structure and inhabit various tissues of seeds, roots, stems and leaves (Johri 2006). The exact role of such endophytic community is not yet very clear but few experiments were conducted with micropropagated sugarcane plants suggests the positive colonization and its contribution to plant growth and development in terms of plant height, nitrogenase activity, leaf nitrogen biomass and yield. Field trials conducted in sugarcane with Glucanoacetobacter diazotrophicus with other diazotrophs can match yield level equal to $275 \mathrm{~kg}$ N/ha application (Sevilla et al., 2001; Muthukumarasway et al., 2002; Oliveria et al., 2002).

Prevalence of endophytic PGPR strain in sugarcane has been recently established and their antagonistic activity against red rot pathogen was identified (Viswanathan and Samiyappan 2002). Glick (1994) studied that mycorrhiza plays major role in terms of resistance to bacterial and fungal pathogens, increased photosynthetic rate and enhanced stomatal regulation under water stressed condition in sugarcane. Concerning the above problems the current study was focused on the use of bioinoculants to enhance the sugarcane growth and also to assess the functional potentialities in relation to plant growth promoting activities like IAA, phosphate solubilization and nitrogenase activity with the objectives to study the effect of microbial inoculants on growth and nutrient uptake in sugarcane, standardizing the efficient combination of bioinoculants for maximizing sugarcane productivity and to explore the possibility of reduction in inorganic fertilizer input through bioinoculant application.

\section{Materials and Methods}

The experiment was conducted for a period of 1 year (2010 - 2011) at Sugarcane Research Station, Cuddalore with ten treatments in three replications in a Randomized Block Design. The sugarcane variety taken for the study was CoC24. The maximum and minimum mean temperatures of the location were $31.7^{\circ} \mathrm{C}$ and $24.1^{\circ} \mathrm{C}$, respectively. The mean annual rainfall was $1200 \mathrm{~mm}$. The soil of the experimental field was sandy clay loam, with low available $\mathrm{N}$ (186.84 kg ha-1), medium in available ' $\mathrm{P}$ ' $\left(16.5 \mathrm{~kg} \mathrm{ha}^{-1}\right)$ and medium in available potash $\left(265 \mathrm{~kg} \mathrm{ha}^{-1}\right)$. The $\mathrm{pH}$ of the soil was 7.2. The bioinoculants, viz., Gluconoacetobacter diazotrophicus, AM fungi and Azophos (Azospirillum and phosphobacteria) were used along with inorganic fertilizer. The treatments used in the experiment were as follows: Gluconoacetobacter diazotrophicus $+75 \%$ NPK (T1); AM fungi (colonized root bits) + $75 \%$ NPK (T2); Azophos + $75 \%$ NPK (T3); Gluconoacetobacter diazotrophicus+ AM fungi (colonized root bits) $+75 \%$ NPK (T4); Gluconoacetobacter diazotrophicus + 
Azophos + $75 \%$ NPK (T5); AM fungi (colonized root bits) + Azophos $+75 \%$ NPK (T6); Gluconoacetobacter diazotrophicus + AM fungi (colonized root bits) + Azophos + $75 \%$ NPK (T7); Gluconoacetobacter diazotrophicus+ AM fungi (colonized root bits) + Azophos + 100\% NPK (T8); Recommended NPK (100\%) alone (T9); 75\% of recommended NPK alone (T10);

The data collected on germination count, tiller population, millable cane population cane yield commercial cane sugar per net sugar yield were pooled and analyzed. The population of bioinoculants was enumerated by pour plate technique (James 1958). The soil samples for microbial enumeration were collected before planting, 30 days after planting and 120 days after planting. The available soil nitrogen (Subbiah and Asija 1956), phosphorus (Olsen et al., 1954) and potassium (Standford and English 1949) were analyzed. The yield was recorded along with the quality parameters.

\section{Results and Discussion}

The plant crop was raised during 2010-2011 with sugarcane variety $\mathrm{CoC} 24$. Sett treatment and soil application with bioinoculants was done as per the treatment schedule.

The inorganic fertilizers were also applied as per schedule. Regarding germination and tiller counts, the application of Gluconoacetobacter diazotrophicus@10 kg + AM fungi@ 25 kg/ ha+Azophos@10 kg + 75 \% NPK recorded higher germination of $87.36 \%$ and maximum tiller population of $1,94,185$ / ha (Table 1).

The soil samples were collected before planting and after application of inorganic fertilizers and bioinoculants and were analysed for the microbial population count and also for the dynamics in the soil nutritional status. The bacterial and fungal population was maximum in $G$. diazotrophicus + AM fungi + Azophos + $75 \%$ NPK with $43.33 \times 10^{6} \mathrm{cfu} / \mathrm{ml}, 68.33 \times 10^{7}$ $\mathrm{cfu} / \mathrm{ml}$ and $26.66 \times 10^{4} \mathrm{cfu} / \mathrm{ml}, 45.66 \times 10^{4}$ $\mathrm{cfu} / \mathrm{ml}$ at $45^{\text {th }}$ and $105^{\text {th }}$ day respectively. In case of actinomycetes, the maximum count was recorded in $G$. diazotrophicus $+\mathrm{AM}$ fungi + Azophos $+100 \%$ NPK with 14.33 $\mathrm{x} 10^{4} \mathrm{cfu} / \mathrm{ml}$ and $30.00 \times 10^{4} \mathrm{cfu} / \mathrm{ml}$ (Table 2). The treatment with $G$. diazotrophicus + AM fungi + Azophos $+75 \%$ NPK recorded the maximum population of $\mathrm{G}$. diazotrophicus $\left(39.33 \times 10^{4} \mathrm{cfu} / \mathrm{ml}\right.$ and $\left.44.00 \times 10^{4} \mathrm{cfu} / \mathrm{ml}\right)$, Azospirillum $\left(35.33 \times 10^{4} \mathrm{cfu} / \mathrm{ml}\right.$ and $\mathrm{x} 50.66 \mathrm{x}$ $\left.10^{4} \mathrm{cfu} / \mathrm{ml}\right)$, phosphobacteria $\left(32.00 \times 10^{4}\right.$ $\mathrm{cfu} / \mathrm{ml}$ and $41.00 \quad \times 10^{4} \mathrm{cfu} / \mathrm{ml}$ )and Pseudomonas $\left(46.66 \times 10^{6} \mathrm{cfu} / \mathrm{ml}\right.$ and $\mathrm{x} 52.00$ $\mathrm{x} 10^{6} \mathrm{cfu} / \mathrm{ml}$ ) at $45^{\text {th }}$ and $105^{\text {th }}$ DAP respectively (Table 3). Application of $G$. diazotrophicus + AM fungi + Azophos + $75 \%$ NPK significantly enhanced the total nitrogen content, available phosphorous, potassium and organic carbon content in the soil (Table 4).

Application of G. diazotrophicus @ $10 \mathrm{~kg} / \mathrm{ha}+$ AM fungi @ $25 \mathrm{~kg} / \mathrm{ha}+$ Azophos @ $10 \mathrm{~kg}$ / ha $+75 \%$ of the recommended NPK recorded the maximum mean millable cane population of 1.32 lakhs /ha followed by $G$. diazotrophicus@10 kg + AM fungi@25 kg/ ha+Azophos@10 kg + 100 \% NPK with 1.29 lakhs millable cane / ha. Similar trend was observed with cane yield and sugar yield with $137.45 \mathrm{t} / \mathrm{ha}$ and $16.96 \mathrm{t} / \mathrm{ha}$ respectively with the application of G. diazotrophicus @10 kg/ha+AM fungi@25 kg/ha+Azophos@ $10 \mathrm{~kg} / \mathrm{ha}+75 \%$ of the recommended NPK (Table 5).

The increase in yield and enhanced quality parameters was due to the combined effect of the bioinoculants along with the inorganic fertilizers. 
Table.1 Germination and tiller population of sugarcane plant crop

\begin{tabular}{|c|c|c|c|}
\hline S. No & Treatments & $\begin{array}{c}\text { Germination } \\
\text { percentage }\end{array}$ & $\begin{array}{l}\text { Tiller population } \\
\text { ('000/ha) }\end{array}$ \\
\hline 1 & $\begin{array}{c}\text { G. diazotrophicus }+75 \\
\% \text { NPK }\end{array}$ & 82.93 & 178.72 \\
\hline 2 & AM fungi $+75 \%$ NPK & 77.86 & 175.89 \\
\hline 3 & Azophos + $75 \%$ NPK & 84.09 & 179.21 \\
\hline 4 & $\begin{array}{c}\text { G. diazotrophicus }+ \\
\text { AM fungi }+75 \% \text { NPK }\end{array}$ & 86.06 & 187.57 \\
\hline 5 & $\begin{array}{c}\text { G. diazotrophicus }+ \\
\text { Azophos }+75 \% \text { NPK }\end{array}$ & 86.71 & 188.29 \\
\hline 6 & $\begin{array}{l}\text { AM fungi + Azophos } \\
+75 \% \text { NPK }\end{array}$ & 83.46 & 191.38 \\
\hline 7 & $\begin{array}{l}\text { G. diazotrophicus }+ \\
\text { AM fungi + Azophos } \\
+75 \% \text { NPK }\end{array}$ & 87.36 & 194.11 \\
\hline 8 & $\begin{array}{l}\text { G. diazotrophicus }+ \\
\text { AM fungi }+ \text { Azophos } \\
+100 \% \text { NPK }\end{array}$ & 86.58 & 194.18 \\
\hline 9 & $\begin{array}{l}\text { Recommended NPK } \\
(100 \%) \text { alone }\end{array}$ & 83.20 & 194.16 \\
\hline 10 & $\begin{array}{l}75 \% \text { of recommended } \\
\text { NPK alone }\end{array}$ & 83.46 & 167.67 \\
\hline & Mean & 84.17 & 185.12 \\
\hline & S.Ed & 4.13 & 0.22 \\
\hline & CD (0.05) & 8.67 & 0.46 \\
\hline
\end{tabular}

Table.2 Enumeration of microbial population at 45th and 105th DAP

\begin{tabular}{|c|c|c|c|c|c|c|}
\hline \multirow[t]{2}{*}{ Treatments } & \multicolumn{2}{|c|}{$\begin{array}{c}\text { Bacteria } \\
\left(\times 10^{6} \mathrm{cfu} / \mathrm{ml}\right)\end{array}$} & \multicolumn{2}{|c|}{$\begin{array}{c}\text { Fungi } \\
\left(\mathbf{x 1 0}^{4} \mathrm{cfu} / \mathrm{ml}\right)\end{array}$} & \multicolumn{2}{|c|}{$\begin{array}{l}\text { Actinomycetes } \\
\left(\text { x 10 } 10^{4} \mathrm{cfu} / \mathrm{ml}\right)\end{array}$} \\
\hline & $45^{\text {th }}$ DAP & $105^{\text {th }}$ DAP & $45^{\text {th }}$ DAP & $105^{\text {th }}$ DAP & $45^{\text {th }}$ DAP & $105^{\text {th }} \mathrm{DAP}$ \\
\hline G. diazotrophicus+75\% NPK & 35.66 & 54.00 & 14.02 & 49.00 & 10.66 & 19.66 \\
\hline AM fungi + $75 \%$ NPK & 26.66 & 35.66 & 30.66 & 46.00 & 11.50 & 20.75 \\
\hline Azophos + $75 \%$ NPK & 36.00 & 50.33 & 15.33 & 30.50 & 7.00 & 25.00 \\
\hline $\begin{array}{l}\text { G.diazotrophicus+AM fungi + } 75 \% \\
\text { NPK }\end{array}$ & 36.77 & 49.00 & 20.33 & 40.33 & 10.33 & 19.00 \\
\hline $\begin{array}{l}\text { G.diazotrophicus + Azophos + } 75 \% \\
\text { NPK }\end{array}$ & 41.00 & 50.50 & 13.16 & 31.33 & 11.50 & 20.66 \\
\hline AM fungi+Azophos+75 \% NPK & 39.66 & 47.33 & 23.67 & 29.66 & 10.66 & 21.66 \\
\hline $\begin{array}{l}\text { G.diazotrophicus+ AM } \\
\text { fungi+Azophos+75 \% NPK }\end{array}$ & 43.33 & 68.33 & 26.66 & 45.66 & 13.66 & 28.66 \\
\hline $\begin{array}{l}\text { G.diazotrophicus+ AM fungi + } \\
\text { Azophos }+100 \% \text { NPK }\end{array}$ & 39.66 & 59.00 & 25.12 & 42.66 & 14.33 & 30.00 \\
\hline Recommended NPK $(100 \%)$ alone & 24.66 & 36.33 & 10.66 & 20.66 & 6.66 & 17.33 \\
\hline $75 \%$ of recommended NPK alone & 25.00 & 30.66 & 12.50 & 19.50 & 4.33 & 15.00 \\
\hline Mean & 34.84 & 48.11 & 19.21 & 35.53 & 10.06 & 21.77 \\
\hline
\end{tabular}


Table.3 Enumeration of microbial population at $45^{\text {th }}$ and $105^{\text {th }}$ DAP

\begin{tabular}{|c|c|c|c|c|c|c|c|c|}
\hline \multirow[t]{2}{*}{ Treatments } & \multicolumn{2}{|c|}{$\begin{array}{l}\text { Azospirillum } \\
\left.\text { (x } 10^{5} \mathrm{cfu} / \mathrm{ml}\right)\end{array}$} & \multicolumn{2}{|c|}{$\begin{array}{c}G . \\
\text { diazotrophicus } \\
\left(\times 10^{4} \mathrm{cfu} / \mathrm{ml}\right)\end{array}$} & \multicolumn{2}{|c|}{$\begin{array}{c}\text { Phosphobacter } \\
\text { ia } \\
\left(\times 10^{4} \mathrm{cfu} / \mathrm{ml}\right)\end{array}$} & \multicolumn{2}{|c|}{$\begin{array}{l}\text { Pseudomonas } \\
\left(\times 10^{6} \mathrm{cfu} / \mathrm{ml}\right)\end{array}$} \\
\hline & $\begin{array}{l}\mathbf{4 5}^{\text {th }} \\
\text { DAP }\end{array}$ & $\begin{array}{l}105^{\text {th }} \\
\text { DAP }\end{array}$ & $\begin{array}{l}4^{\text {th }} \\
\text { DAP }\end{array}$ & $\begin{array}{l}105^{\text {th }} \\
\text { DAP }\end{array}$ & $\begin{array}{l}45^{\text {th }} \\
\text { DAP }\end{array}$ & $\begin{array}{l}105^{\text {th }} \\
\text { DAP }\end{array}$ & $\begin{array}{l}45^{\text {th }} \\
\text { DAP }\end{array}$ & $\begin{array}{l}105^{\text {th }} \\
\text { DAP }\end{array}$ \\
\hline G. diazotrophicus + $75 \%$ NPK & 35.66 & 54.00 & 28.02 & 49.00 & 10.66 & 19.66 & 35.66 & $\begin{array}{c}40.3 \\
3\end{array}$ \\
\hline AM fungi + $75 \%$ NPK & 26.66 & 35.66 & 19.66 & 26.00 & 9.50 & 20.75 & 39.00 & $\begin{array}{c}44.1 \\
5\end{array}$ \\
\hline Azophos + $75 \%$ NPK & 36.00 & 50.33 & 15.33 & 22.50 & 20.00 & 32.00 & 37.66 & $\begin{array}{c}41.7 \\
0\end{array}$ \\
\hline G.diazotrophicus+ AM fungi + $75 \%$ NPK & 36.77 & 49.00 & 22.33 & 40.33 & 10.33 & 19.00 & 41.66 & $\begin{array}{c}45.5 \\
0\end{array}$ \\
\hline G.diazotrophicus + Azophos + $75 \%$ NPK & 41.00 & 50.50 & 23.16 & 39.33 & 18.50 & 28.66 & 37.66 & $\begin{array}{c}45.0 \\
0\end{array}$ \\
\hline AM fungi + Azophos + $75 \%$ NPK & 39.66 & 47.33 & 16.67 & 27.66 & 15.66 & 25.66 & 40.33 & $\begin{array}{c}40.3 \\
3\end{array}$ \\
\hline $\begin{array}{l}\text { G.diazotrophicus+ AM fungi + Azophos + } 75 \% \\
\text { NPK }\end{array}$ & 43.33 & 68.33 & 26.66 & 45.66 & 20.33 & 30.00 & 46.66 & $\begin{array}{c}52.0 \\
0\end{array}$ \\
\hline $\begin{array}{l}\text { G.diazotrophicus+ AM fungi + Azophos + } 100 \% \\
\text { NPK }\end{array}$ & 39.66 & 59.00 & 25.12 & 44.66 & 19.66 & 28.66 & 42.66 & $\begin{array}{c}49.0 \\
0\end{array}$ \\
\hline Recommended NPK (100\%) alone & 24.66 & 36.33 & 10.66 & 15.66 & 6.66 & 15.33 & 20.66 & $\begin{array}{c}23.6 \\
6\end{array}$ \\
\hline $75 \%$ of recommended NPK alone & 25.00 & 30.66 & 12.50 & 19.50 & 4.13 & 14.00 & 20.00 & $\begin{array}{c}28.6 \\
6\end{array}$ \\
\hline Mean & 34.84 & 48.11 & 19.21 & 35.53 & 10.06 & 21.77 & 36.20 & $\begin{array}{c}41.0 \\
3\end{array}$ \\
\hline
\end{tabular}

Table.4 Effect of combined application inorganic fertilizers with bioinoculants on available potassium and organic carbon content in soil

\begin{tabular}{|c|c|c|c|c|}
\hline \multirow[t]{2}{*}{ Treatment } & \multicolumn{2}{|c|}{ Available Potassium (kg/ha) } & \multicolumn{2}{|c|}{$\begin{array}{c}\text { Organic carbon } \\
\text { content }(\%)\end{array}$} \\
\hline & $45^{\text {th }}$ DAP & $105^{\text {th }}$ DAP & $45^{\text {th }}$ DAP & $105^{\text {th }}$ DAP \\
\hline G. diazotrophicus + $75 \%$ NPK & 35.66 & 54.00 & 28.02 & 49.00 \\
\hline AM fungi + $75 \%$ NPK & 26.66 & 35.66 & 19.66 & 26.00 \\
\hline Azophos + $75 \%$ NPK & 36.00 & 50.33 & 15.33 & 22.50 \\
\hline G.diazotrophicus+AM fungi + $75 \%$ NPK & 36.77 & 49.00 & 22.33 & 40.33 \\
\hline G.diazotrophicus+Azophos + $75 \%$ NPK & 41.00 & 50.50 & 23.16 & 39.33 \\
\hline AM fungi+Azophos+75 \% NPK & 39.66 & 47.33 & 16.67 & 27.66 \\
\hline G.diazotrophicus+ AM fungi+Azophos+75 \% NPK & 43.33 & 68.33 & 26.66 & 45.66 \\
\hline G.diazotrophicus+ AM fungi +Azophos+100\% NPK & 39.66 & 59.00 & 25.12 & 44.66 \\
\hline Recommended NPK (100\%) alone & 24.66 & 36.33 & 10.66 & 15.66 \\
\hline $75 \%$ of recommended NPK alone & 25.00 & 30.66 & 12.50 & 19.50 \\
\hline Mean & 188.36 & 185.22 & 0.15 & 0.20 \\
\hline S.Ed & 3.16 & 4.42 & 1.12 & 1.74 \\
\hline $\mathrm{CD}(0.05)$ & 6.74 & 8.95 & 2.45 & 2.98 \\
\hline
\end{tabular}


Table.5 Effect of combined application of bio inoculants with NPK fertilizers on yield attributes, juice quality, cane and sugar yield

\begin{tabular}{|c|c|c|c|c|c|}
\hline $\begin{array}{l}\text { S. } \\
\text { No. }\end{array}$ & Treatments & $\begin{array}{c}\text { Millable cane } \\
\text { population ('000/ha.) }\end{array}$ & $\begin{array}{l}\text { Cane } \\
\text { yield }\end{array}$ & $\begin{array}{c}\text { CCS } \\
\%\end{array}$ & $\begin{array}{l}\text { Sugar } \\
\text { yield }\end{array}$ \\
\hline 1. & G. diazotrophicus $+75 \%$ NPK & 120.0 & 126.12 & 9.92 & 12.51 \\
\hline 2. & AM fungi $+75 \% \mathrm{NPK}$ & 117.2 & 123.56 & 9.72 & 12.01 \\
\hline 3. & Azophos + $75 \%$ NPK & 118.7 & 125.79 & 9.80 & 12.33 \\
\hline 4. & $\begin{array}{l}\text { G.diazotrophicus + AM fungi }+75 \% \\
\text { NPK }\end{array}$ & 124.8 & 131.25 & 10.34 & 13.57 \\
\hline 5. & $\begin{array}{l}\text { G.diazotrophicus + Azophos + } 75 \% \\
\text { NPK }\end{array}$ & 123.5 & 130.55 & 10.22 & 13.34 \\
\hline 6. & AM fungi + Azophos + $75 \%$ NPK & 121.2 & 129.84 & 9.95 & 12.92 \\
\hline 7. & $\begin{array}{l}\text { G.diazotrophicus + AM fungi + } \\
\text { Azophos }+75 \% \text { NPK }\end{array}$ & 128.4 & 137.45 & 10.70 & 14.96 \\
\hline 8. & $\begin{array}{l}\text { G.diazotrophicus + AM fungi }+ \\
\text { Azophos }+100 \% \text { NPK }\end{array}$ & 125.2 & 133.62 & 10.50 & 14.03 \\
\hline 9. & Recommended NPK (100\%) alone & 120.8 & 128.19 & 10.50 & 12.88 \\
\hline \multirow[t]{3}{*}{10.} & $75 \%$ of recommended NPK alone & 95.70 & 107.15 & 10.05 & 10.52 \\
\hline & S.Ed & 4.21 & 3.55 & 0.82 & 0.68 \\
\hline & CD & 8.47 & 7.14 & NS & 1.38 \\
\hline
\end{tabular}

The biofertilizers application enhanced the yield and quality parameters and also essential to maintain soil microflora population and protect soil fertility from deterioration. Significant changes in various plant growth parameters have been shown by the inoculation of various nitrogen fixing and plant growth promoting bacteria (Nayak et al., 1986; Murty and Ladh 1988; Gunarto et al., 1999). Sevilla et al., (1998), have shown the benefits to sugarcane growth by using Nif mutants of Acetobacter. In addition to nitrogen fixation the beneficial effects has been attributed to the production of plant growth hormones also (Sevilla et al., Kennedy 2000).

Application of phosphorous from different sources, i.e., from inorganic and as bioinoculants (AM fungi and phosphobacteria) was found to be effective in sugarcane. Continuous availability of the valuable nutrients and their persistence and colonization in soil makes the soil more fertile and healthy. The mobilization of $\mathrm{P}$ from soil to the plants is mediated by hairy root systems of the mycorrhizal fungi through plant roots. It commonly infect plant roots, including those of sugarcane forming beneficial symbiotic relationships (Kelly et al., 1997).

The improvement in plant growth was attributed to an enhanced access of mycorrhizal root to soil phosphorous located beyond the rhizosphere (Sanders and Tinker 1973) and infection by mycorrhizal fungi is significantly rduced at high soil phosphorous levels (Amijee et al., 1989). Mycorrhiza was found to be compatible with nitrogen fixers viz., Rhizobium (Hayman 1986), Acetobacter and phosphate solubilising bacteria (Bagyaraj and Menge 1978; Singh and Kapoor 1999). It also holds good for sugarcane. The inoculation of bioinoculants is beneficial for sugarcane growth for increasing the plant vigour at lower nitrogen levels, consequently the amount of 
fertilizer could be reduced. AM fungi and phosphobacteria are very much essential to convert the unavailable form of the phosphorous source to available source and providing to the plants. The usage of these bioinoculants in turn reduces the inorganic fertilizer input and thereby reduces the cost of cultivation. With this reference these bioinoculants can be recommended for their use in nutrient management and enhanced sugarcane productivity.

\section{Acknowledgements}

The authors are grateful to the Head, Sugarcane Research Station Cuddalore, for providing all the facilities for carrying out the research and also Tamil Nadu Agricultural University for providing financial support for the research.

\section{References}

Amijee F, Tinker PB, Stribley DP (1989). The development of endomycorrhizal root systems VII A detailed study of effects of soil phosphorous on colonisation. New phytol 111: 453-446.

Glick BR (1994). The enhancement of plant growth by free living bacteria. Canadian Journal of Microbiology 41: 109-117.

Gold stein (1986). Response of sugarcane to calcium silicate slag on everglades. Annual Review of Plant Physiology and Plant Molecular Biology 50(1): $641-9$

Gunarto L, Adchi K, Senboku L (1999). Isolation and selection of indigenous Azospirillum spp. from a subtropical island and effect if inoculation on growth of low land rice under several levels of N application. Biol Fertile Soils 28: 129-135
Hayman H (1986). Response of sugarcane to silicate source and rate growth and yield. Phytopathology 93(4): 402-412.

Johri H (2006). Response of sugarcane to nitrogen source and rate of growth and yield. Agron J 74: 481-4

Kelly RM, Edwards DG, Magarey RC, Thompson JP (1997). The effect of VAM on the growth and nutrition of sugarcane. Proc Aust Soc Sug cane Technol 19: 73-79

Murthy MG, Ladha JK (1988). Influence of Azospirillum inoculation on the mineral uptake and growth of rice under hydrophonic conditions. Plant \& Soil 108:281-285

Muthukumarasamy R, Revathy G, Loganathan $P$ (2002). Effect of inorganic $N$ on the population in vitro colonization and morphology of Acetobacter. Plant \& Soil 243: $91-102$

Nayak DN, LAdha LK, Watanabe I (1986). The fate of marker $A$. lipoferum inoculated and its effect on growth, yield and $\mathrm{N}$ fixation. Biol Fertile Soils 2: 7-14

Oliveria ALM, Urquiaga S, Dobrenier J, Baldani JI (2002). The effect of inoculating endophytic $\mathrm{N}$ fixing bacteria on micropropogated sugarcane plants. Plant \& Soil 242: 205-215

Sanders FE, Ticker PB (1973). Phosphate flow into mycorrhizal roots. Pesticide Science 4; 385-395

Sevilla M, Burris RH, Gunapala N, Kennedy C (2001). Comparison of benefits of sugarcane plant growth with Acetobacter inoculation in wild type and Nif mutant strains. Mol Plant Microbe Interaction 14: 358 - 366

Sevilla M, Oliveria D, Baldani I, Kenedy C (1998). Contributions of the bacterial endophyte of Acetobacter to sugarcane nutrition: a preliminary study. Symbiosis 25: 181-191 
Singh, Kapoor (1999). Silicon nutrition and sugarcane cultivation. J Plant Nutr 15(7): $1-10$

Viswanathana R, Samiyappan B (2002). Induced systemic resistance by fluorescent pseudomonads against red rot disease of sugarcane caused by Colletotrichum falcatum. Crop Protection 21: 1 - 10.

Yadav S, Prasad H (1992). nitrogenase activity of sugarcane propagated from stem cuttings on sterile vermiculite. Soil Biol Biochem 12: 413- 417

Yaduvanshi, Yadhav (1990). Isolation and characterisation of genetically two distant group of Acetobacter from new host plant. J Appl Bacteriol 86: 10531058

Standford S, English, L (1949). Use of flame photometer in rapid soil tests of $\mathrm{K}$ and Ca. Agron. J. 4:446-447.

Olsen SR, Cole F, Watanabe S, Dean AL (1954). Estimation of available phosphorus in soil by extraction with sodium bicarbonate. USDA. Circ.939.

Subbiah B V, Asija CL (1956). A rapid procedure for estimation of available nitrogen in soils. Curr. Sci. 25: 259260.

\section{How to cite this article:}

Jamuna, E. and Pandiyan, M. 2019. Study on Sustaining Sugarcane Productivity through Mobilization of Nutrients using Bio-Inoculants. Int.J.Curr.Microbiol.App.Sci. 8(10): 344-351. doi: https://doi.org/10.20546/ijcmas.2019.810.035 